\title{
Medicolegal study of sexual violence cases in Pekanbaru, Indonesia: prevalence, pattern, and Indonesian legal framework
}

\author{
Dedi Afandio
}

\begin{abstract}
Background: Sexual violence is a major public health problem. The role of forensic examination is very important for collecting evidence on sexual violence cases. The principal aim of this study was to identify the prevalence and pattern of injury in sexual violence victims. In this study, sexual violence in terms of the Indonesian legal framework, especially medicolegal procedures and terms of rape, will also be discussed.

Methods: Data for this retrospective study were retrieved from the medicolegal reports (Visum et Repertum) of sexual violence victims obtained from the Forensic Medical Service Center (FMSC) Bhayangkara Hospital Pekanbaru (BHP) over five years starting from January 1, 2010, until the end of December 2014.

Result: The average prevalence rate of sexual violence was 13.15/100,000 population/year. The total number of cases was 665 , and $94.6 \%$ were females. Adolescents composed the highest proportion of cases among both genders. Bruises and abrasions were the most frequent injuries found (17.1\% and $14.3 \%$, respectively), with the upper extremity being the most common site. Most victims had ano-genital injury (75.2\%), but $77.6 \%$ had no bodily injury. There was a significant difference between children and adults regarding bodily injury $(P=0.028)$, and there was a significant difference between males and females regarding ano-genital injury $(P=0.000)$.

Conclusion: The prevalence of sexual violence was high among living victims in Pekanbaru, with the majority of victims being female. The Indonesian legal framework of sexual violence still adheres to traditional terminology but is making improvements.
\end{abstract}

Keywords: Forensic examination finding, Indonesian legal framework, Medicolegal, Pattern, Prevalence, Sexual violence

\section{Background}

Sexual violence is a major public health problem. Sexual violence occurs throughout the world in low-, middleand high-income countries. Although most studies report that the majority of victims are female, sexual violence can also occur in men (Krug et al., 2002). A survey in the United States (US) (2010) reported that 1 in 5 women (18.3\%) and 1 in 71 men (1.4\%) have been raped at some point in their lives, including attempted or completed rape (Black et al., 2011). Sexual violence affects all age groups: children, adolescents and adults. Sexual violence victims can experience physical violence, mental health consequences, and other health consequences, such as sexually

Correspondence: dediafandi4n6@gmail.com

Forensic Medicine and Medicolegal Studies Department, Faculty of Medicine, Universitas Riau, Diponegoro street No 1, Pekanbaru, Riau, Indonesia transmitted disease, pregnancy and sexual dysfunction. These consequences can occur immediately or in the medium-long term. More severe consequences can include hospitalization, disability and death (Black et al., 2011; Jina \& Thomas, 2017; Moreno, 2013).

Laws and policies for addressing sexual violence cases vary between countries. Some countries have their own definition of sexual violence and other forms of sexual violence (Krug et al., 2002). It is important to know the legal framework in cases of sexual violence to ensure that the management of victims and preventive actions can be performed in accordance with the laws and social norms prevailing in the country (World Health Organization, 2015).

The role of forensic examination is very important to prove the occurrence of sexual violence through the examination of forensic medicine, including collecting 
evidence and generating a medicolegal report. The medical doctor obtains the history of violence, performs a physical examination, documents examination findings, collects evidence, and interprets and analyzes the findings (Cybulska \& Forster, 2010; Ingemann-Hansen \& Charles, 2013; Quadara et al., 2013; Welch \& Mason, 2007; World Health Organization, 2003).

In Indonesia, data from the Annual Report National Commission on Anti-Violence Against Women of the Republic of Indonesia (Indonesian National Commission on Violence Against Women, 2017) revealed that sexual violence ranked second in 2016 in violence against women cases, an increase compared with the rank of third in 2014. The most significant form of sexual violence in women is rape $(72 \%)$, followed by obscenity $(18 \%)$ and sexual harassment (5\%). Regarding investigations of sexual violence, only a few studies have reported the prevalence of sexual violence in Indonesia. Hayati et al. (2011) reported that the prevalence of lifetime exposure to sexual violence was $22 \%$ among women in rural areas (Hayati et al., 2011). A study in the 3 provinces in Indonesia reported that the incidence of sexual violence in men ranged between $1.5 \%$ and $1.8 \%$ (Jewkes et al., 2013). There are no data regarding the prevalence of sexual violence in hospital settings, especially in urban areas.

\section{Aim of the work}

Pekanbaru is the capital city of the Riau Province, one of the 34 provinces in Indonesia. This city is the third largest (inland) urban area on Sumatra Island, with a population of $1,011,467$ people. Pekanbaru is a heterogeneous city with 3 major tribes, namely, Malay, Minang and Batak, and there are also other tribes, such as Java, Bugis, Nias and Tionghoa (Statistic of Pekanbaru City 2015). The principal aim of this study was to identify the prevalence of and pattern of injury in sexual violence based on records from the Forensic Medical Service Center (FMSC) at Bhayangkara Hospital Pekanbaru (BHP). This hospital is a teaching hospital of the Faculty of Medicine, Universitas Riau, and the hospital center for forensic medical services in Pekanbaru. All sexual violence cases reported to the police are referred to BHP. In this paper, sexual violence in terms of the Indonesian legal framework, especially medicolegal procedures and terms of rape, will also be discussed.

\section{Methods}

This was a 5-year retrospective study. The data were retrieved from the medicolegal reports (Visum et Repertum) of living victim cases referred by police investigators to the FMSC at BHP during a period of five years starting from January 1, 2010, until the end of December 2014. The determinations of sexual violence cases were based on the medicolegal report (visum et repertum) and the police's official inquiry letter. Overall, the total number of medicolegal injury reports of living victims in the FMSC during the study period was 6876, and 665 were identified as sexual violence cases.

The completeness of the data was ensured by collecting and recording the necessary data that were contained in the medicolegal reports (Visum et Repertum) of sexual violence cases. The demographic characteristics included sex, age, and occupation. The pattern of injury included bodily injury (presence of wound and site of wound) and ano-genital injury. Official approval was obtained from the Director of BHP. Complete confidentiality was ensured throughout the study. Ethical approval was granted by the Institutional Ethics Committee of the Faculty of Medicine, Universitas Riau.

A literature search was conducted to identify and understand the Indonesian legal framework related to sexual violence. The main literary sources used are the law related to sexual crimes (i.e., the Indonesian's Code of Criminal Procedure; the Indonesian Penal Code; The Children Rights Protection Law No.23 Year 2002 and Amending Law on Child Protection No. 35 of 2014; The Elimination of Violence in Household Law No.23 Year 2004) and additional articles that were relevant to sexual violence.

The collected data were analyzed using Statistical Package for the Social Sciences (SPSS) (SPSS Inc., Chicago, IL, US), version 21.0. For qualitative variables, a descriptive analysis was performed, and the results are presented as frequencies (percentages). The frequency of quantitative variables was calculated and represented by the mean (Standard Deviation (SD)) or median values if the data were not normally distributed. The chi-square test and other appropriate statistical tests were used to identify significant associations or perform comparisons between two qualitative variables. A $p$-value less than 0.05 was considered significant.

\section{Results \\ Prevalence and pattern of sexual violence cases}

The total number of cases was 665 during the five years of the present study. The trend line of number of sexual violence victims decreased across the years, with children composing the majority of sexual violence victims and females outnumbering males in each of the study years (Fig. 1). The average prevalence rate of sexual violence was 13.15/100,000 population/year. Regarding intellectual and developmental disorder evaluation, in our study we found no victims with intellectual and developmental disability among study populated.

Table 1 illustrates the age and sex distribution of sexual violence cases; specifically, 94.6\% were females $(n=629)$, and $5.4 \%$ were males $(n=36)$, with a female-to-male ratio of 19.1:1. The mean age was $15.05 \pm 6.45$ years, and there was a significant difference between males and females with respect to age $(P<0.05)$. 


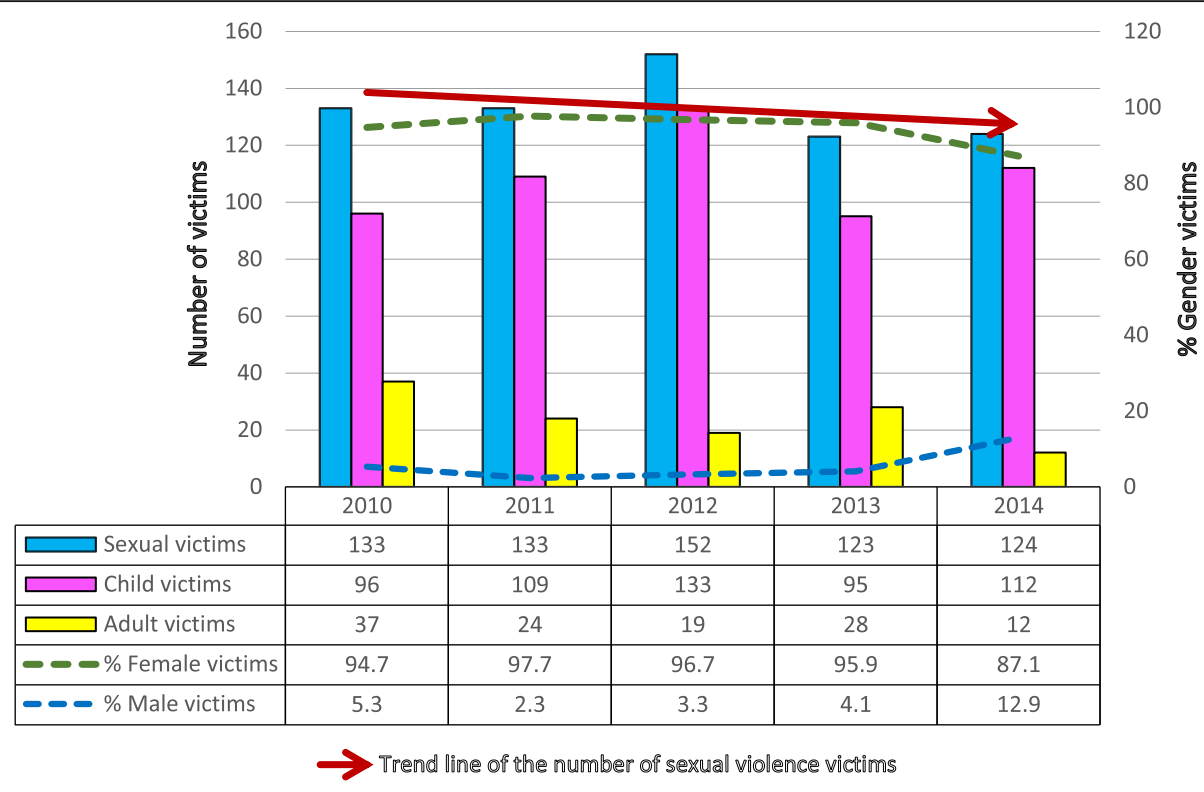

Fig. 1 The number of sexual violence victim cases, child and adult victims and percentage of victims by gender per year

Eighty-two percent and 18\% of the victims were children and adults, respectively. The ages of victims ranged from 1 to 70 years, with a median age of 16 years. The most affected age groups were aged 5 to 9 years old (38.9\%) for males and aged 5 to $<18$ years old (44.5\%) for females (Table 2). There was no significant difference between gender and age category $(P=0.119)$. Most of the sexual violence victims were students (75\%) (Fig. 2).

Bruises and abrasions were the most frequent injury found in the sexual violence victims $(17.1 \%$ and $14.3 \%$, respectively). Vulnus laceratum, vulnus scissum and burns were not found as frequently in males compared with females. The most common wound site was the upper extremities (6.2\%) (Table 3).

Acute and old hymenal tears were found in $42.8 \%$ and $30.2 \%$ of females, respectively. Both an acute tear and old hymenal tear could be found in one victim. Among males, most victims had no abnormal findings in the perianal examination, and only $12.1 \%$ had the presence of a lesion on the male genitalia. Bruises and/or abrasions were found in the perianal area in $27.3 \%$ of males and $3 \%$ of females (Table 4).

Table 1 Age comparison between male and female cases of sexual violence in Pekanbaru, Indonesia $(n=665)$

\begin{tabular}{llllll}
\hline Sex & Number & Percent & Median (years) & Mean (SD) & $P$-value \\
\hline Male & 36 & 5.4 & $10(2-23)$ & $11.03(5.29)$ & 0.000 \\
Female & 629 & 94.6 & $16(1-70)$ & $15.28(6.44)$ & \\
Total & 665 & 100 & $16(1-70)$ & $15.05(6.45)$ & \\
\hline
\end{tabular}

*Mann-Whitney U Test, $P$-values $\leq 0.05$ were considered significant
Most victims had an ano-genital injury (75.2\%), and $77.6 \%$ had no bodily injury. In this study, there was a significant difference between children and adults with respect to bodily injury $(P=0.028)$ and ano-genital injury $(P=0.000)$, and there was a significant difference between males and females regarding ano-genital injury $(P=0.000)$ (Table 5).

Table 2 Association of age category and age group with gender in sexual violence cases in Pekanbaru, Indonesia $(n=665)$

\begin{tabular}{|c|c|c|c|c|}
\hline \multirow[t]{2}{*}{ Age } & \multicolumn{2}{|l|}{ Gender } & \multirow{2}{*}{$\begin{array}{l}\text { Total } \\
\text { n (\%) }\end{array}$} & \multirow[t]{2}{*}{$P$-value } \\
\hline & Male $\mathrm{n}(\%)$ & $\overline{\text { Female n (\%) }}$ & & \\
\hline \multicolumn{5}{|l|}{ Age category } \\
\hline Children & 33 (91.7) & $512(81.4)$ & $545(82)$ & \multirow[t]{3}{*}{0.119} \\
\hline Adult & $3(8.3)$ & 117 (18.6) & $120(18)$ & \\
\hline Total & $36(100)$ & $629(100)$ & $665(100)$ & \\
\hline \multicolumn{5}{|c|}{ Age group, year } \\
\hline $0-4$ & $3(8.3)$ & $33(5.2)$ & $36(5.4)$ & \multirow[t]{11}{*}{0.000} \\
\hline $5-9$ & $14(38.9)$ & $74(11.8)$ & $88(13.2)$ & \\
\hline $10-14$ & $10(27.8)$ & 125 (19.9) & $135(20.3)$ & \\
\hline $15-<18$ & $6(16.7)$ & $280(44.5)$ & $286(43.0)$ & \\
\hline $18-24$ & $3(8.3)$ & $83(13.2)$ & $86(12.9)$ & \\
\hline $25-34$ & $0(0.0)$ & $25(4.0)$ & $25(3.8)$ & \\
\hline $35-44$ & $0(0.0)$ & $7(1.1)$ & $7(1.1)$ & \\
\hline $45-54$ & $0(0.0)$ & $1(0.2)$ & $1(0.2)$ & \\
\hline $55-64$ & $0(0.0)$ & $0(0.0)$ & $0(0.0)$ & \\
\hline $65-74$ & $0(0.0)$ & $1(0.2)$ & $1(0.2)$ & \\
\hline Total & $36(100)$ & $629(100)$ & 665 (100) & \\
\hline
\end{tabular}




\section{Occupation of victims}

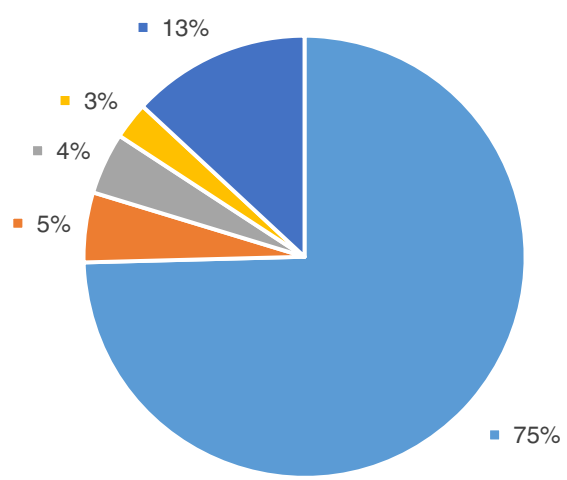

- Student

- Housewife

- Irregular limited, income work

- Regular limited, income work

- Others

Fig. 2 Distribution of cases according to victim occupation

Indonesian legal framework of sexual violence

Based on Indonesian's Criminal Code Procedure (Act of The Republic of Indonesia, 1981), investigations of suspected sexual violence cases are conducted in Indonesia as follows. Victims or the parents or guardians of a child who has been assaulted report the situation to the police, and the police refer them to the hospital with an official inquiry letter. In this letter, the police investigator writes the type of case (sexual crime). By order from the police's official inquiry letter, the medical doctor performs a forensic examination of the sexual violence victim. Although a medicolegal examination is based on a request from a police investigator, informed consent should still be made before the examination is performed. This is because the

Table 3 Distribution of cases according to bodily injury by gender among sexual violence cases

\begin{tabular}{|c|c|c|c|}
\hline \multirow[t]{2}{*}{ Variable } & \multicolumn{2}{|l|}{ Gender } & \multirow{2}{*}{$\begin{array}{l}\text { Total } \\
(\mathrm{n}=665) \\
\mathrm{n}(\%)\end{array}$} \\
\hline & $\begin{array}{l}\text { Male }(n=33) \\
\mathrm{n}(\%)\end{array}$ & $\begin{array}{l}\text { Female }(\mathrm{n}=629) \\
\mathrm{n}(\%)\end{array}$ & \\
\hline \multicolumn{4}{|l|}{ Presence of wound } \\
\hline Abrasion & $4(12.1)$ & $110(17.5)$ & $114(17.1)$ \\
\hline Bruise & $7(21.2)$ & $88(14.0)$ & $95(14.3)$ \\
\hline Vulnus laceratum & $0(0.0)$ & $6(0.9)$ & $6(0.9)$ \\
\hline Vulnus scissum & $0(0.0)$ & $2(0.3)$ & $2(0.3)$ \\
\hline Burn & $0(0.0)$ & $1(0.1)$ & $1(0.1)$ \\
\hline \multicolumn{4}{|l|}{ Site of wound } \\
\hline Head & $1(3.0)$ & $25(4.0)$ & $26(3.9)$ \\
\hline Upper extremity & $4(12.1)$ & $37(5.9)$ & $41(6.2)$ \\
\hline Lower extremity & $4(12.1)$ & $16(2.5)$ & $20(3.0)$ \\
\hline Neck & $0(0.0)$ & $21(3.3)$ & $21(3.1)$ \\
\hline Chest & $0(0.0)$ & $17(2.7)$ & $17(2.6)$ \\
\hline Back & $0(0.0)$ & $9(1.4)$ & $9(1.3)$ \\
\hline Abdomen & $0(0.0)$ & $4(0.6)$ & $4(0.6)$ \\
\hline
\end{tabular}

victim is also a patient, and the area to be examined is a "sensitive" area (Gopalakrishnan et al., 2016). A medicolegal report is created by the medical doctor after the medical forensic examination is performed. When a case requires other specialist involvement, the forensic doctor will refer to the appropriate specialist, the victim will be referred to the gynecologist if it requires wound care of the genital area, ensures the pregnancy of the victim or when emergency contraception is necessary to prevent pregnancy; if there is an indication of psychological disorders post trauma or mental health evaluation is required then the victim will be referred to psychiatrist. In addition, the victim may also be referred to pediatrician if the child suspected of being sexually assaulted is found with a

Table 4 Forensic examination findings of the perianal-genital area in sexual violence cases

\begin{tabular}{lll}
\hline Variable & $\begin{array}{l}\text { Male }(\mathrm{n}=33) \\
\mathrm{n}(\%)\end{array}$ & $\begin{array}{l}\text { Female }(\mathrm{n}=629) \\
\mathrm{n}(\%)\end{array}$ \\
\hline $\begin{array}{l}\text { Female genitals } \\
\text { Hymen tears }\end{array}$ & $\mathrm{N} / \mathrm{A}$ & \\
- Acute (partial/complete) & & $269(42.8)$ \\
- Old (partial/complete) & & $190(30.2)$ \\
- Acute and old & $\mathrm{N} / \mathrm{A}$ & $75(11.9)$ \\
Erythema & & \\
Male genitals & $4(12.1)$ & $\mathrm{N} / \mathrm{A}$ \\
Presence of lesion & & \\
$\begin{array}{l}\text { Perianal } \\
\text { Perianal erythema }\end{array}$ & $2(6.1)$ & $5(0.8)$ \\
Bruise and/or abrasion & $9(27.3)$ & $19(3.0)$ \\
Reduced tone of anal sphincter & $3(9.1)$ & $7(1.1)$ \\
Anal laceration & $1(1.0)$ & $1(0.2)$ \\
Scar & $1(1.0)$ & $0(0.0)$ \\
Fold change & $1(1.0)$ & $2(0.3)$ \\
\hline
\end{tabular}


Table 5 Association of bodily injury and ano-genital injury with gender and age category

\begin{tabular}{|c|c|c|c|c|c|c|c|c|}
\hline \multirow[t]{2}{*}{ Variable } & \multicolumn{2}{|l|}{ Gender } & \multirow[t]{2}{*}{ Total } & \multirow[t]{2}{*}{$P$-value } & \multicolumn{2}{|c|}{ Age category } & \multirow[t]{2}{*}{ Total } & \multirow[t]{2}{*}{$P$-value } \\
\hline & Male & Female & & & Children & Adults & & \\
\hline \multicolumn{9}{|c|}{ Bodily injury } \\
\hline - yes & $10(27.8)$ & $139(22.1)$ & $149(22.4)$ & 0.427 & $113(20.7)$ & $36(30.0)$ & $149(22.4)$ & 0.028 \\
\hline- no & $26(72.2)$ & $490(77.9)$ & $516(77.6)$ & & $432(79.3)$ & $84(70.0)$ & $516(77.6)$ & \\
\hline \multicolumn{9}{|c|}{ Ano-genital injury } \\
\hline - yes & $9(25.0)$ & & & 0.000 & & & & 0.000 \\
\hline- no & $27(75.0)$ & $\begin{array}{l}491(78.1) \\
138(21.9)\end{array}$ & $\begin{array}{l}500(75.2) \\
165(24.8)\end{array}$ & & $\begin{array}{l}441(80.9) \\
104(19.1)\end{array}$ & $\begin{array}{l}52(49.2) \\
61(50.8)\end{array}$ & $\begin{array}{l}500(75.2) \\
165(24.8)\end{array}$ & \\
\hline
\end{tabular}

growth disorder, a sexually transmitted infection, or an injury requiring treatment (Gopalakrishnan et al., 2016). In the Indonesian legal system, a medicolegal report for legal and judicial interest is called Visum et Repertum (VeR). The main difference between this report and other medical examination reports is the inclusion of the word "Pro Justicia" in front of Visum et Repertum, but the content of the letters is the same. The legal basis of Visum et Repertum is article 133 of Indonesian's Criminal Act Procedure (Act of The Republic of Indonesia, 1981):

\section{Article 133}

(1) in case an investigator for the sake of justice handles the problem of a victim, whether he is injured, poisoned or dead presumably because of an event involving a criminal act, he is authorized to submit a request for expert information from a medical expert of the judiciary or a doctor and/or other expert.

(2) The request for expert information as intended in section (1) shall be made in writing, by stating firmly whether it shall be for the examination of an injury or a dead person and/or an autopsy.

In Indonesia, based on article 133 of Indonesian's Criminal Act Procedure (Act of The Republic of Indonesia, 1981), forensic doctor is mandated to take a history and perform a general and vaginal examination on any alleged victims of sexual crimes. However, due to the small number of forensic doctors (less than 200) in Indonesia, the law allows for the examination of alleged victims of sexual crimes by general physicians or other specialists. Forensic doctor in Indonesia practice as forensic pathologist and clinical forensic medicine (Gopalakrishnan et al., 2016). It is an obligation for every doctor in Indonesia to make Visum et Repertum if requested by the investigator. Based on Indonesian's Penal Code article 216, doctors who refuse to conduct medical examinations of crime victims and refuse to make Visum et Repertum at the request of the investigator can be punished by a maximum imprisonment of four months and two weeks or a maximum fine of six hundred rupiahs (Act of The Republic of Indonesia, 1946).
Sexual violence is a criminal offense in Indonesia, and similar to most other countries, Indonesia also has laws related to sexual violence. Indonesian's Penal Code No. 1 Year 1946 (Act of The Republic of Indonesia, 1946), The Children Rights Protection Law No.23 Year 2002 (Act of The Republic of Indonesia, 2002) and The Elimination of Violence in Household Law No.23 Year 2004 (Act of The Republic of Indonesia, 2004) are laws that are often used and encountered in cases of sexual violence. Table 6 shows a collection of articles of the prevailing laws and regulations in Indonesia and their interpretation.

\section{Discussion}

\section{Prevalence and pattern}

Sexual violence cases constitute a large proportion of violent crimes and is a serious problem. Many sexual violence cases have been reported in Pekanbaru. This study evaluated the number of sexual violence victims who were examined in FMSC at BHP based on referrals from police investigators. The average prevalence of sexual violence in the study population was $13.15 / 100,000$ population/year. This result is similar to the rate that was recorded for sexual violence victims in Aarhus from 1999 to 2004, which was 14.5/100,000 (Ingemann-Hansen et al., 2009). This proportion is lower than that found in a study by Saltzman et al. in the United States, which reported a rate of 25/100,000 inhabitants (i.e., both sexes and all ages) (Saltzman et al., 2007). This difference may be explained by the Indonesian culture, in which victims feel ashamed to report the sexual violence they experience to the police, or it may be due to the lack of a database, different sources of data collection, different methods of study and different numbers of victims.

Most sexual violence victims are female. In this study, $94.6 \%$ of sexual violence victims were female, which is similar to other previous studies that reported that most sexual violence occurs in females, with prevalence's of 93.9\% in Taipei (Hwa et al., 2010), 98.3\%) in India (Tamuli et al., 2013), 82.7\% in Turkey (Karanfil et al., 2013), 97\% in Aarhus-Denmark (Ingemann-Hansen et al., 2009) and 92.6\% in the US (Avegno et al., 2009). The results of this study further strengthen the notion that sexual violence is 


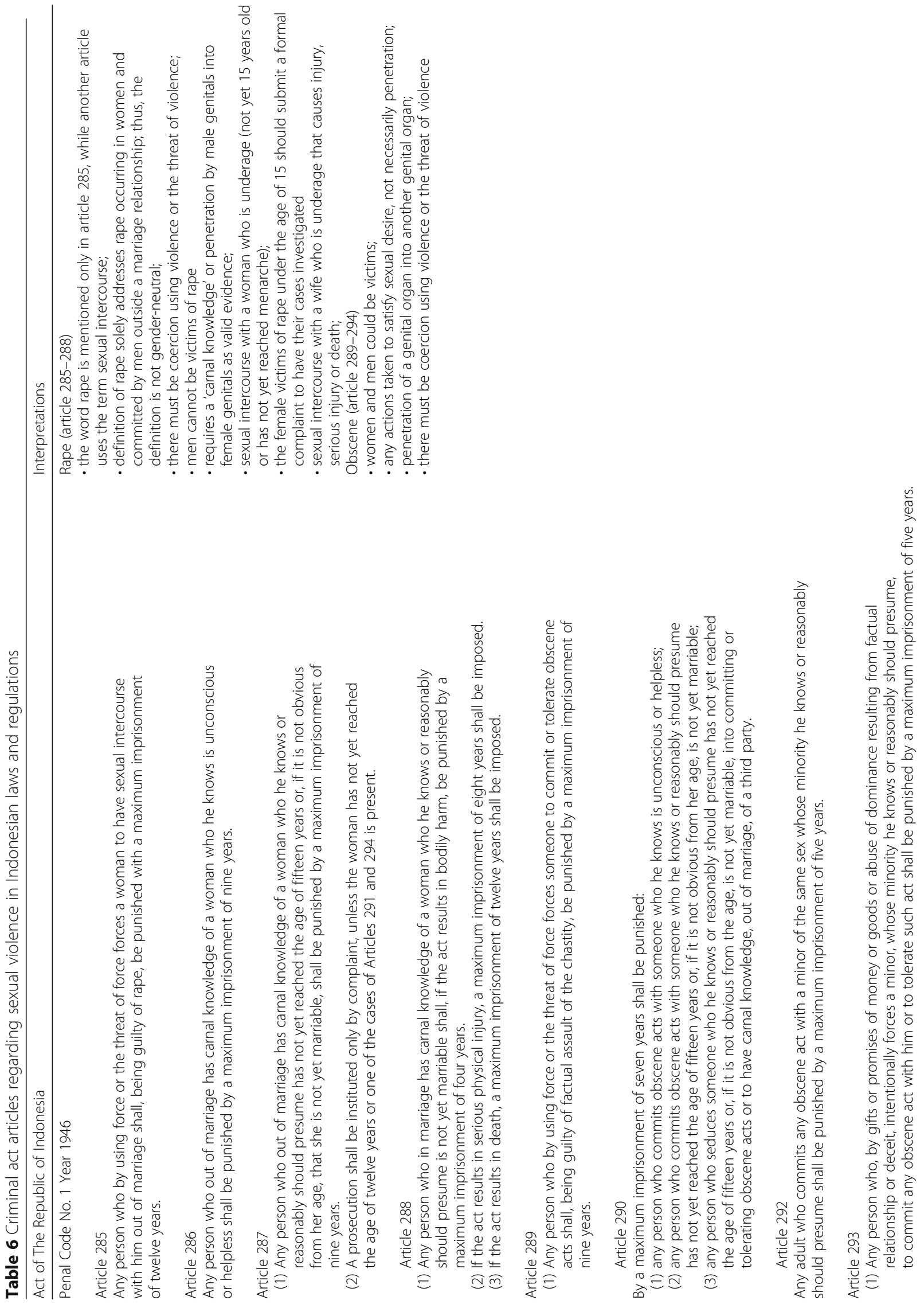




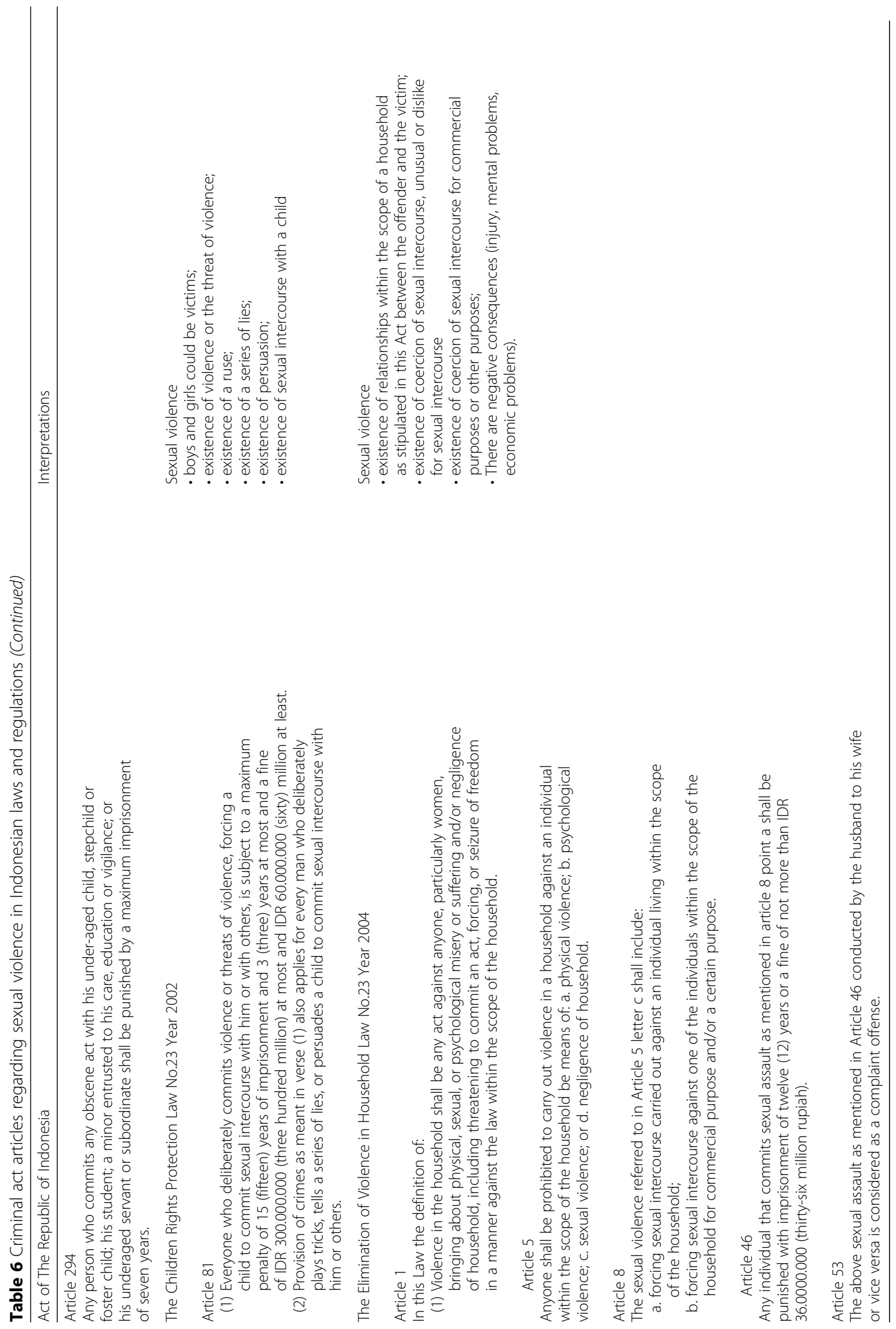


one of the most common crimes against women. The proportion of sexual violence victims in this study who were men was 5.4\%. Studies in Taipei (Hwa et al., 2010), India (Tamuli et al., 2013), Aarhus-Denmark (Ingemann-Hansen et al., 2009) and the US (Avegno et al., 2009) also reported male victim proportions to be less than $10 \%$. This number is lower than that found in a study in Turkey by Karanfil et al. (2013), which reported a male victim incidence of $17.3 \%$. This difference may be explained by the cultural norms and gender inequity in the Indonesian legal framework. The findings in this study indicate that both males and females could be victims of sexual violence.

Our study revealed that $82 \%$ and $18 \%$ of the sexual violence victims were children and adults, respectively. The number of child victims of sexual violence in this study was higher than that in a study conducted in Taipei, who reported a $64 \%$ proportion of child victims of sexual violence (Hwa et al., 2010). In contrast to previous studies, other studies reported that most victims were adults, namely, 54\% in Spain (Moreno, 2013) and 66\% in Aarhus-Denmark (Ingemann-Hansen et al., 2009). This finding may reflect that being young (a child or a teenager) is already a prognostic factor of vulnerability and that children are the main targets of perpetrators (Nannini, 2006). This fact also validates the high level of parental awareness of children at risk for sexual violence and the effects of the mass media influence in combating sexual crimes against children. Our study showed that the most affected age group in boys was the range from 5 to 9 years old (38.9\%), and the most affected age group in girls ranged from 15 to $<18$ years old $(44.5 \%)$. This result is of particular concern and demonstrates that parents and the community should pay more attention to the more vulnerable age groups of victims of sexual violence.

Our study reported that $22.4 \%$ of sexual violence victims had bodily injury. The results were lower than those of previous studies reporting rates of $30.6 \%$ in Spain (Moreno, 2013), 41.8\% in Taipei (Hwa et al., 2010) and $42 \%$ in Italy (Zerbo et al., 2018). Nevertheless, all of these studies reported similar patterns to those in our study, namely, the incidence of physical injury increased as the victim age increased (Hwa et al., 2010; Moreno, 2013). This study also showed a significant association between bodily injuries in children and adults. The two most common types of injuries found in this study were similar to those found in a study in Spain, namely, bruises and abrasions, with the extremities being the most common site of injury (Moreno, 2013; Zerbo et al., 2018). More child victims had ano-genital injuries compared with adult victims. There was a significant difference between children and adults regarding bodily injury $(P=0.028)$ and ano-genital injury $(P=0.000)$.

Regarding forensic examination findings of the ano-genital area, the percentages of victims with genital/anal lesions
(75.2\%) in our study were higher than those in a previous study by Hwa et al. (2010) (Hwa et al., 2010), which reported a prevalence of $53.3 \%$. This difference may be explained by the different number of victims, different number of male victims and different number of victims in each age category.

In this study, more of the child victims had an ano-genital injury compared with the adult victims. There was a statistically significant difference between children and adults regarding ano-genital injury $(P=0.000)$ and a significant difference between males and females regarding ano-genital injury $(\mathrm{P}=0.000)$.

\section{Indonesian legal framework of sexual violence}

Sexual violence terminology is not found in the Indonesian Penal Code (Act of The Republic of Indonesia, 1946), while sexual violence terminology is contained in The Children Rights Protection Law No.23 Year 2002 (Act of The Republic of Indonesia, 2002) and The Elimination of Violence in Household Law No.23 Year 2004 (Act of The Republic of Indonesia, 2004). The Indonesian Penal Code only mentions two forms of sexual violence: rape and obscenity (Act of The Republic of Indonesia, 1946). The term 'sexual violence' is much broader than the term 'rape' because sexual violence can include various other forms of sexually lewd acts, sexual harassment and other behaviors. While the term used in the Penal Code is a crime against decency, it does not use the term 'sexual violence,' which is defined as a criminal act related to sexuality that can be performed against men or women. The use of the term 'morality' causes the public, especially legal professionals, to be trapped in placing the articles of morality solely as a matter of violation of cultural values, religious norms, or courtesy relating to sexual lust, not a crime against one's body and soul (Novirianti, 2010).

In Indonesian's Penal Code, the definition of rape solely states that rape occurs in women and is committed by men outside a marriage relationship. Proof of rape in the Indonesian Penal Code requires the occurrence of sexual intercourse between men and women outside of marriage committed by violence and/or threats of violence. Sexual intercourse is defined as the entry of the male genitals into the female genitals with or without ejaculation (Novirianti, 2010).

Thus, the term 'male rape' is not present in the Indonesian Penal Code. A crime in which a man who suffers sexual violence committed by men or women is categorized as obscenity. The broader definition of rape began to be adopted by several countries (United Kingdom (UK), US, Australia and others) and stated that rape could be gender-neutral, meaning that it can apply to any person of either sex or gender (Lowe \& Rogers, 2017; World Health Organization, 2015). 
Another issue related to sexual violence is sexual violence in marriage (marital rape). Although it has been a law for more than a decade, the effectiveness of the law against sexual violence in marriage enacted in The Elimination of Violence in Household Law No.23 Year 2004 is not clearly visible. Similar to most other Islamic countries, it is impossible to define rape in the context of marriage even if it can happen. The Indonesian marriage law has created an unequal position between wives and husbands, as it considers that "husbands are the head of household". Indonesia makes a similar cultural assumption that marriages are harmonious because husbands and wives agree at all times (Novirianti, 2010; Riggins, 2004; Susila, 2013; Tongat, 2017). The Indonesian Council of Ulama declared that sexual assault in marriage can be considered unlawful sexual violence if the following situation or conditions are present: the wife is in a state of menstruation, at the moment of parturition, during Ramadhan fasting, and/or anal sex (Susila, 2013).

In addition to the developments in the international world and the influence of globalization, Indonesia is currently drafting laws on sexual violence. Indonesia is also amending the Penal Code. The handling of sexual violence cases in the legal context is expected to improve and reduce the incidence of sexual violence in Indonesia.

Our study has some limitations. It was based on medicolegal reports of sexual violence victims. It contains only data relevant to justice and law enforcement. Moreover, the history of perpetrators, living environment of victims, and type of sexual abuse were not available in the medicolegal report. The incidence of male victims was low (5.4\%), but they were included in all analyses.

\section{Conclusion and Recommendations.}

In conclusion, this study highlighted the prevalence of sexual assault cases in Pekanbaru, Indonesia. Although sexual violence cases may affect both sexes and all ages, females and adolescents should be given more attention. The Indonesian legal framework of sexual violence still adheres to traditional terminology but is making improvements.

An international standard should be adopted in the management of sexual violence victims. Developments in this area should include improved facilities and infrastructure as well as increased understanding and ability of the parties involved. Recording, documentation and database storage need to be addressed to provide more complete and comprehensive information for the development of preventive, promotive, curative and rehabilitative programs for sexual violence.

\section{Abbreviations}

VeR: Visum et Repertum; FMSC: Forensic Medical Service Center; BHP: Bhayangkara Hospital Pekanbaru; WHO: World Health Organization; SPSS: Statistical Package for the Social Sciences; SD: Standard Deviation; UK: United Kingdom; US: United State

\section{Acknowledgements}

I thank to Director of Bhayangkara Hospital Pekanbaru for her permission, Annisa Riandsya B.Med.Sci and administrative staff of Medicine and Health Department Riau Regional Police for assistance to collect medicolegal report.

\section{Availability of data and materials}

The data used and/or analyzed in this study are available from the corresponding author on reasonable request.

\section{Author's contributions}

DA participated in the design the study protocol of the study, was responsible for statistical analysis, interpretation of the results, and drafted the manuscript, given final approval of the version to be published and agreed to be accountable for all aspects of the work.

\section{Author's information}

DA is Dean of Faculty of Medicine, Universitas Riau and Associate Professor. He has a PhD degree in Forensic Medicine and Medicolegal studies. He has written several scientific publications on gender-based violence, domestic violence, child abuse and neglect.

Ethics approval and consent to participate

Being a retrospective study, official approval was obtained from Director of Bhayangkara Hospital Pekanbaru. Complete confidentiality was ensured all through the study procedure. The research protocol was approved by the the Institutional Ethics Committee of the Faculty of Medicine, Universitas Riau (No. 52/UN19.1.28/UEPKK/2015).

\section{Competing interests}

The author declares that he have no competing interests.

\section{Publisher's Note}

Springer Nature remains neutral with regard to jurisdictional claims in published maps and institutional affiliations.

Received: 31 January 2018 Accepted: 15 May 2018

Published online: 24 May 2018

\section{References}

Act of The Republic of Indonesia Number 11946 on The Penal Code

Act of The Republic of Indonesia Number 232002 on The Children Rights Protection Law

Act of The Republic of Indonesia Number 232004 on The Elimination of Violence in Household Law

Act of The Republic of Indonesia Number 81981 on The Penal Code of Criminal Procedure

Avegno J, Mills TJ, Mills LD (2009) Sexual assault victims in the emergency department: analysis by demographic and event characteristics. J Emerg Med 37(3):328-334

Black MC, Basile KC, Breiding MJ, Smith SG, Walters ML, Merrick MT et al (2011) The national intimate partner and sexual violence survey (NISVS): 2010 summary report. National Center for Injury Prevention and Control, Centers for Disease Control and Prevention, Atlanta, GA

Cybulska B, Forster G (2010) Sexual assault: examination of the victim. Medicine 38(5):235-238

Gopalakrishnan H, Syukriani Y, Setiawati E (2016) Forensic experts' opinion regarding clinical forensic medicine practice in Indonesia and Malaysia. J Forensic Sci Med 2(2):85-90

Hayati EN, Högberg U, Hakimi M, Ellsberg MC, Emmelin M (2011) Behind the silence of harmony: risk factors for physical and sexual violence among women in rural Indonesia. BMC Womens Health 11:52. https://doi.org/10.1186/1472-6874-11-52

Hwa HL, Chen SC, Wu MZ, Shun CT, Liu SK, Lee JCl et al (2010) Analysis of cases of sexual assault presenting at a medical center in Taipei. Taiwan J Obstet Gynecol 49(2):165-169. https://doi.org/10.1016/S1028-4559(10)60035-6

Indonesian National Commission on Violence Against Women (2017) Annual notes on violence against women 2016 fact sheet, demanding the State to be active in the elimination of violence against women in the Personal, Community and National Sphere. [Internet] [cited 9 April 2017] retrieved from: http://en.komnasperempuan.go.id/reads-komnas-perempuan-annualnotes-on-violence-against-women-2016-fact-sheet-demanding-the-state-tobe-active-in-the-elimination-of-violence-against-women-in-the-personalcommunity-and-national-sphere 
Ingemann-Hansen O, Charles AV (2013) Forensic medical examination of adolescent and adult victims of sexual violence. Best Pract Res Clin Obstet Gynaecol 27:91-102

Ingemann-Hansen O, Sabroe S, Brink O, Knudsen M, Charles AV (2009) Characteristics of victims and assaults of sexual violence - improving inquiries and prevention. J Forensic Legal Med 16:182-188

Jewkes R, Fulu E, Roselli T, Garcia-Moreno C (2013) Prevalence of and factors associated with non-partner rape perpetration: findings from the UN multicountry cross-sectional study on men and violence in Asia and the Pacific. Lancet Glob Heal 1:e208-e218

Jina R, Thomas LS (2017) Health consequences of sexual violence against women. Best Pract Res Clin Obstet Gynaecol 27:15-26

Karanfil R, Keten A, Zeren C, Arslan MM, Eren A (2013) Evaluation of sexual assaults in Turkey. J Forensic Legal Med 20:404-407

Krug E, Dahlberg L, Mercy J, Zwi A, Rafael L (2002) World report on violence and health. World Health Organization, pp 147-181

Lowe M, Rogers P (2017) The scope of male rape: a selective review of research, policy and practice. Aggress Violent Behav 35:38-43

Moreno A (2013) Age differences among victims of sexual assault: a comparison between children, adolescents and adults. J Forensic Legal Med 20:465-470

Nannini A (2006) Sexual assault patterns among women with and without disabilities seeking survivor services. Womens Health Issues 16(6):372-379

Novirianti D (2010) Indonesian Law and policy on rape: Paralegals and access to justice for rape victims. Available from: https://www.lunduniversity.lu.se/lup/ publication/1890570

Quadara A, Fileborn B, Parkinson D (2013) The role of forensic medical evidence in the prosecution of adult sexual assault. 1-31 p

Riggins L (2004) Criminalizing marital rape in Indonesia. Third World L J 24(2): 421-441 Available from: http://lawdigitalcommons.bc.edu/twlj/vol24/iss2/6

Saltzman LE, Basile KC, Mahendra RR, Steenkamp M, Ingram E, Ikeda R (2007) National estimates of sexual violence treated in emergency departments. Ann Emerg Med 49:210-217

Statistic of Pekanbaru City (2015) Pekanbaru in figures 2015. 63-71 p. In: Available from https://pekanbarukota.bps.go.id/publication/2015/12/10/ 4bfcbcfbb963d47e9045ed8d/kota-pekanbaru-dalam-angka-2015.html

Susila M (2013) Islamic perspective on marital rape. Jurnal Media Hukum 20(2): 317-332 Available from: http://journal.umy.ac.id/index.php/jmh/article/view/ $271 / 234$

Tamuli RP, Paul B, Mahanta P (2013) A statistical analysis of alleged victims of sexual assault a retrospective study. J Punjab Acad forensic. Med Toxicol 13(1):7-13 Available from: http://medind.nic.in/jbc/t13/i1/jbct13i1p7.pdf

Tongat Al (2017) Marital rape in Indonesian criminal law perspective. Journal of Law, Policy and Globalization 59:134-138 Available from: http://www.iiste. org/Journals/index.php/JLPG/article/viewFile/36163/37158

Welch J, Mason F (2007) Rape and sexual assault. Br Med J 334:1154-1158

World Health Organization (2003) Guidelines for medico-legal care for victims of sexual violence. World Health Organization $154 \mathrm{p}$

World Health Organization (2015) Sexual health, human rights and the law. In: 1-48 p

Zerbo S, Milone L, Scalici E, Procaccianti S, Nardello R, Ventura Spagnolo E et al (2018) Medico legal procedures related to sexual assault: a 10-year retrospective experience of a Daphne protocol application. Egypt J Forensic Sci 8(1):4. https://doi.org/10.1186/s41935-018-0039-9

\section{Submit your manuscript to a SpringerOpen ${ }^{\circ}$ journal and benefit from:}

- Convenient online submission

- Rigorous peer review

- Open access: articles freely available online

- High visibility within the field

- Retaining the copyright to your article

Submit your next manuscript at $>$ springeropen.com 